\title{
Correction to: Long non-coding RNA XIST regulates gastric cancer progression by acting as a molecular sponge of miR-101 to modulate EZH2 expression
}

Dong-liang Chen ${ }^{1 \dagger}$, Huai-qiang Ju ${ }^{1 \dagger}$, Yun-xin Lu ${ }^{1+}$, Le-zong Chen ${ }^{1 \dagger}$, Zhao-lei Zeng ${ }^{1}$, Dong-sheng Zhang ${ }^{1}$, Hui-yan Luo ${ }^{1}$, Feng Wang ${ }^{1}$, Miao-zhen Qiu', De-shen Wang ${ }^{1}$, Da-zhi Xu' ${ }^{1}$, Zhi-wei Zhou' ${ }^{1}$, Helene Pelicano², Peng Huang ${ }^{2}$, Dan Xie ${ }^{1}$, Feng-hua Wang ${ }^{1}$, Yu-hong $\mathrm{Li}^{1}$ and Rui-hua Xu ${ }^{1 *}$

\section{Correction to: J Exp Clin Cancer Res 35, 142 (2016) https://doi.org/10.1186/s13046-016-0420-1}

Following the publication of the original article [1], the authors identified that mismatched images had been used in Fig. 6; specifically the panels "Si-XIST(\#2)+miR101 inhibitor" in Fig. 6c. The corrected figure is given below. The correction does not affect the conclusion of the article. The original article has been corrected.

\section{Author details}

'State Key Laboratory of Oncology in South China, Collaborative Innovation Center for Cancer Medicine, Sun Yat-sen University Cancer Center, Guangzhou, PR China. ${ }^{2}$ University of Texas M.D. Anderson Cancer Center, Houston, TX, USA.

Published online: 24 June 2021

\section{Reference}

1. Chen DL, Ju HQ, Lu YX, Chen LZ, Zeng ZL, Zhang DS, et al. Long noncoding RNA XIST regulates gastric cancer progression by acting as a molecular sponge of miR-101 to modulate EZH2 expression. J Exp Clin Cancer Res. 2016;35(1):142.

\footnotetext{
The original article can be found online at https://doi.org/10.1186/s13046016-0420-1.

* Correspondence: xurh@sysucc.org.cn

${ }^{\dagger}$ Dong-liang Chen, Huai-qiang Ju, Yun-xin Lu and Le-zong Chen contributed equally to this work.

'State Key Laboratory of Oncology in South China, Collaborative Innovation

Center for Cancer Medicine, Sun Yat-sen University Cancer Center, Guangzhou, PR China

Full list of author information is available at the end of the article
}

(c) The Author(s). 2021 Open Access This article is licensed under a Creative Commons Attribution 4.0 International License, which permits use, sharing, adaptation, distribution and reproduction in any medium or format, as long as you give appropriate credit to the original author(s) and the source, provide a link to the Creative Commons licence, and indicate if changes were made. The images or other third party material in this article are included in the article's Creative Commons licence, unless indicated otherwise in a credit line to the material. If material is not included in the article's Creative Commons licence and your intended use is not permitted by statutory regulation or exceeds the permitted use, you will need to obtain permission directly from the copyright holder. To view a copy of this licence, visit http://creativecommons.org/licenses/by/4.0/ The Creative Commons Public Domain Dedication waiver (http://creativecommons.org/publicdomain/zero/1.0/) applies to the data made available in this article, unless otherwise stated in a credit line to the data. 

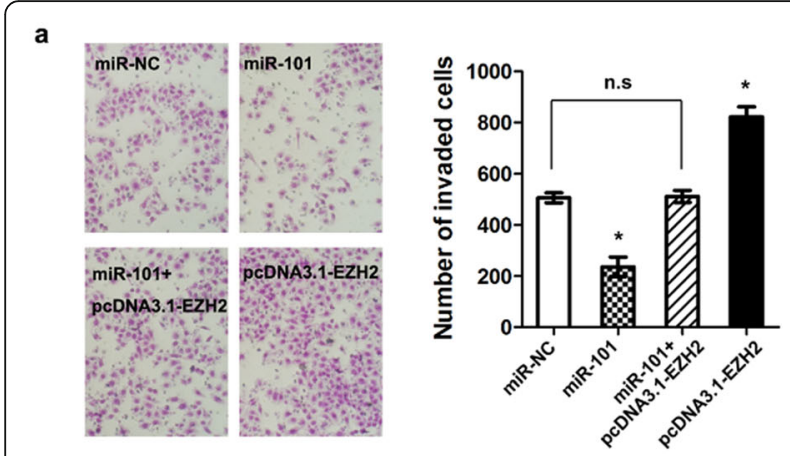

b
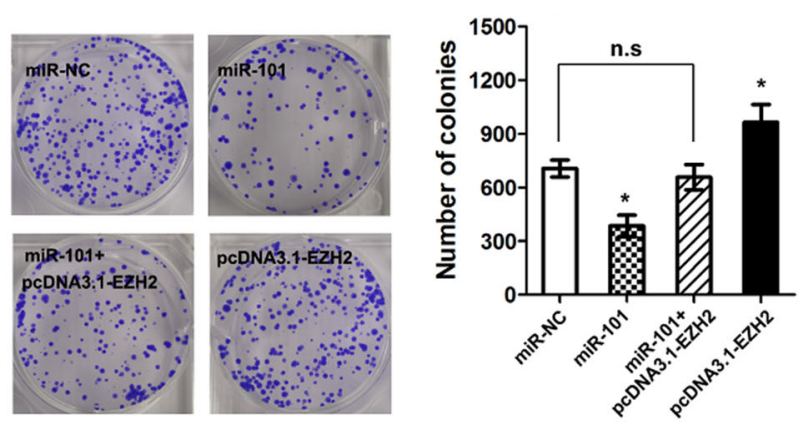

c
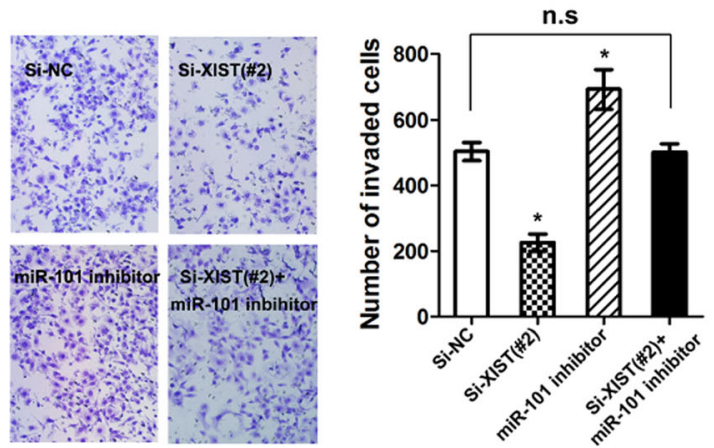

d
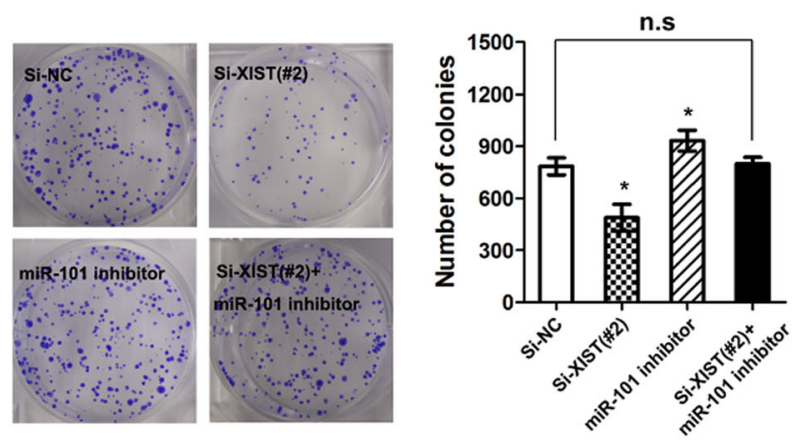

Fig. 6 EZH2 expression mediated the biological effects exerted by IncRNA XIST. a and $\mathbf{b}$ Cell invasion and colony formation assay following ectopic expression of miR-101 and/or EZH2 expression vector lacking the $\left.3^{\prime}-U T R{ }^{*} P<0.05\right)$. $\mathbf{c}$ and $\mathbf{d}$ Cell invasion and colony formation assay following knockdown of IncRNA XIST and/or inhibition of miR-101 $(* P<0.05)$ 